\title{
The Effect of Root and Tuber Technologies Adoption Among Cooperative Farmers in Imo State Agricultural Development Programme
}

\author{
Ikechukwu. E. Ngoka ${ }^{1}$, Ngozi C. Umeobi ${ }^{1}$, Faith. O. Ezeh ${ }^{2}$ \& Helen. O. Nduka ${ }^{2}$ \\ ${ }^{1}$ Department of Business Administration, Federal Polytechnic, Oko, Anambra State, Nigeria \\ ${ }^{2}$ Department of Cooperative Economics and Management, Faculty of Management Sciences, Nnamdi Azikiwe \\ University, Awka, Anambra State, Nigeria \\ Correspondence: Faith. O. Ezeh, Department of Cooperative Economics and Management, Faculty of Management \\ Sciences, Nnamdi Azikiwe University, Awka, Anambra State, Nigeria.
}

Received: Nobember 15, 2019 Accepted: Nobember 27, 2019 Online Published: Nobember 28, 2019
$\begin{aligned} & \text { doi:10.5430/jbar.v8n2p37 } \\ & \text { URL: https://doi.org/10.5430/jbar.v8n2p37 }\end{aligned}$

\begin{abstract}
This study set out to examine the effect of root and tuber technologies adoption among cooperative farmers in Imo State ADP. Four specific objectives and hypotheses were examined and tested. Descriptive survey design was adopted. Taro Yamane sampling techniques was used to determine a sample size of 113 from the population of 338. A simple percentage/frequency distribution model and mean model were used to analyze specific objectives while linear regression model was used to test hypotheses 1 and 4 while Pearson correlation model with Z-Test was used to test hypotheses 2-3. Findings revealed that various varieties and technologies promoted in the area by Root and Tuber Extension Programme - ADP were ABANA 85, ADAKA 96 and EKPE 88 for Yam, while TMS 305SS, TMS 30 and TMS 30572 for Cassava. Comparatively the income levels of the farmers after adoption was significantly improved and they expressed satisfaction with the use of RTEP technologies. The study concluded that a significant relationship exists between the level of adoption and the level of awareness of RTEP - ADP Technologies by cooperative farmers and accessibility of RTEP- ADP technologies in the study area put together. Recommendations were made based on findings which include improved farming technologies by ADP should always be made available to the farmers at a far reduced or subsidized costs to encourage more farmers to access it, also adequate information for training on production, processing and marketing of their farm produce should be made available most especially at the farmers' cooperative society level among others.
\end{abstract}

Keywords: Root and tuber, technology, cooperative farmers, Agriculture, development, extension services, adoption

\section{Introduction}

Roots and tubers mostly notably cassava, sweet potato, yam and potatoes (Solanum/Irish) are some of the most important primary crops. They play a critical role in the global food system, particularly in the developing world, where they bank among the top 10 food crops (Scott, Alex, \& Chris, 2001; Philips, Wilison, \& George, 2004; Nweke, 2004). By 1997, the production of roots and tubers in developing countries had an estimated annual value of more than 41Billion U.S dollars or nearly one fourth the values of the major cereals (Scott et al., 2001). Roots and tubers contribute to the energy and nutrition requirements of more than 2 billion people. They constitute an important source of income in rural and marginal areas and have multiple uses, most notably as food security crops, regular food crops, cash crops and more also are increasingly used as livestock feed and raw material for industrial purpose, (Alexandratos, 2015) Scott et al. (2001), simply put that they have long served as the principal source of food and nutrition for many of the world's poorest and undernourished households and are generally valued for their stable yields under conditions in which other crops may fail.

According to FAO (2000), Nigeria produces roughly $46 \%$ of all the root and tuber crops in Africa, being the biggest producer of cassava and yams. FAO (2000), maintained that root and tuber crops contribute more than 600 calories per capita per day in countries like, Angola, Democratic Republic of Congo, Congo-Brazzavailla, Central African Republic, Mozambique, Ghana, Cote d'Ivoire, Rwanda, Togo and Benin. Despite the importance of riots and tubers in Africa, African and Nigerian food/Agricultural policy over the last half a century has fraud on achieving growth and self-sufficiency in cereals such as wheat, rice and maize, with growth rates in roots and tubers over this period largely driven by area expansion as opposed to yields resulting from technological innovations such as improved 
varieties and production techniques (Scott et al., 2000; Nweke, 2004)

Historically, the production of roots and tubers in Nigeria has been restricted to assuring food security. Due to lack of participatory policy making and institutional development, virtually all succeeding government neglected their production and trade in favour of oil (crude oil) and cash crops such as tea, coffee, cotton, and cocoa (Nweke, 2004). This long neglect of roots and tubers led to prolonged use of (not necessarily high yielding) traditional varieties and production techniques.

Nigerian government in their effort to encourage farmers and increase roots and tubers crop production came up with Root and Tuber Expansion Programme (RTEP). According to Ugwu, Felix and Dixion (2009), RTEP was designed by the Food and Agricultural Development Organization in conflict with the Federal Government of Nigeria following the completion of Cassava multiplication Project (CMP). Ugwu, et al. (2009), put it that, in December 1999, the International Fund for Agricultural Development (IFAD) approved a credit of 23.05million U.S. Dollars to the Federal Government of Nigeria for RTEP. The main thrust of the programme was to consolidate gains made under the Cassava Multiplication Programme (CMP) in order to enhance national food security and income for poor farmers.

Various investigations have shown that membership and participation in a cooperative increase the uptake of technological innovations (Deji 2005; Nwakwo, Peters, \& Bolkemann, 2009). But no single study carried out, addresses the poor awareness of new technology on roots and tuber by the farmers, relevance of the technology to the needs and aspiration of the farmers, inadequate personnel to operate or manage the technology, and the overall farmers' interest in the technology particularly in Imo State thereby leaving a gap in the literature. The researchers therefore deem it necessary to conduct a study examining the effect of root and tuber technologies adoption among cooperative societies (farmers) participating in ADP of Imo State with specific objectives to; find out the RTEP technologies being promoted; determine the farmers' level of awareness of various varieties of root and tuber technologies; determine the level of adoption of RTEP technologies among cooperative farmers; and examine the influence of RTEP technologies on farmers' income in the study area.

\subsection{Hypotheses}

$\mathbf{H o}_{1}$ : The RTEP technologies being promoted are not significantly influenced by farmers' gender, age, educational level, farm size and income.

$\mathbf{H o}_{2}$ : There is no significant relationship between the adoption of various varieties of root and tuber technology and the level of awareness by the farmers in the study area.

Ho $_{3}$ : There is no significant relationship between cooperative farmers' level of adoption and accessibility of RTEPADP technologies.

Ho$_{4}$ : The income level of the farmers is significantly influenced by the adoption of RTEP processing technologies in the study area.

\subsection{Theoretical Framework; Adoption Theory}

Rogers (1995) states that adoption theory has its origin in the explanation of the adoption of technological change by farmers. The first edition of Roger's influential text on the adoption of innovations was published in 1962. Since then the scope of adoption theory and associated empirical research has broadened. Adoption literature largely covers innovations in industrial and service settings; a good deal of attention has now also been paid to public service and public policy innovations with considerable emphasis on the diffusion of innovations in the health care and educational fields (Nutley \& Davies, 2000). Rogers (1995) points out that adoption is not a single, all-encompassing theory. It is several theoretical perspectives that relate to the overall concept of adoption; it is a meta-theory (Yates, 2001). There are four factors that influence adoption of an innovation (Rogers, 1995), including: the innovation itself; the communication channels used to spread information about the innovation; time; the nature of the society to whom it is introduced.

This theory holds that adoption of an innovation grows slowly and gradually in the beginning. It will then have a period of rapid growth that will taper off and become stable and eventually decline (Rogers, 1995). The Bass model suggests other representations (Robert-Ribes \& Wing, 2004). Another aspect of importance is time. Innovations are seen to be communicated across space and through time. Time has been identified as being significant in the diffusion of innovations in three main ways (Rogers \& Scott, 1997). Firstly, the adoption of an innovation is viewed as a mental process that evolves over time starting and initial awareness and initial knowledge about an innovation which evolves into an attitude towards that innovation. This influences the decision of whether to adopt of reject the 
innovation. Secondly, the rate of adoption amongst individuals differs throughout the social system. This starts of slowly with only a minority of people adopting the innovation increasing over time eventually reaching the rate where enough individuals have adopted the innovation and the rate of adoption becomes self-sustaining. Thirdly, time is involved in the rate of adoption or rather the relative speed that members of a social system adopt innovations. This is often measured as the number of members of the system that adopt the innovation in a given time period.

\subsection{Summary of the Literature (Gap in the Literature)}

In this literature review, ADPs was found to represent a truly innovative approach to agricultural and rural development in Nigeria. They were set up to promote agricultural and rural development especially among the small scale farmers which include; the supply of farm inputs through farm services centres; provision of improved seeds; provision of rural infrastructure such as rural roads, construction of dams and boreholes for water supply among others. In their efforts to revitalize and revamp agriculture, this programme made available integrated supply of farm inputs, infrastructural support to farmers and the application of technologies to agriculture.

For any technology to be adopted, it must be relevant to the needs and aspiration of the end user. For instance, there would be no need for an early maturing variety of cowpea or rice if there are no mechanical dryers to dry them as soon as they are harvested. Also, there would not be any need for a tractor mounted tuber harvester if there are no tractors. As a matter of fact, technologies must be demand-driven not supply driven before they can be adopted.

In the empirical review, Madu and Wakili (2012) and Amadi, Eluwa, Agu and Achu (2013) in their separate submissions agreed that ADP project has positively and significantly impacted on rural farmers' productivity, income, access to credit, standard of living as measured by assets ownership. But they however pointed out that, the project did not have significant impact on the rural infrastructure, adoption of improved technologies and farm sizes, even though the change before and after ADP activities was positive.

Nsoanya and Nenna (2011) from their findings submitted affirmed that some yield increasing technologies such as application of fertilizer, use of herbicides and insecticides had not been appreciably adopted by the farmers in Anambra State as a result of high cost of fertilizer, agro-chemicals and unavailability of market.

Ezeh, Anyiro, Ogbonnaya and Obioma (2013) submitted by adding that the ADP impacted positively and significantly on rural women contact farmers' farm income, farm size and fertilizer use levels which tend to agree with the findings of Madu and Wakili (2012) and Amadi, Eluwa, Agu and Achu (2013). Ekwere, Edem and Agbasi (2014) in their submission disagreed with these authors on the income status of farmers before and after adoption of ADP technologies stating that the income levels of the farmers remained unchanged though they expressed satisfaction with the use of RTEP technologies.

Okoedo-Okojie and Onemolease (2000) submitted that age, farm size, farming experience and contact with extension agents had significant influence on farmers' adoption of improved yam storage technology. These authors identified ignorance of technology existence, non-availability and high cost of the some of the storage technologies as major constraints limiting the farmers' adoption of these technologies.

In all these researches, and the availability of new and improved technologies to farmers, it was observed that some areas were still affected by one problem or the other which included high cost of technologies, lack of awareness, and disparity in the income levels of farmers before and after adoption among others. Are all these problems applicable to cooperative farmers in Imo State? Are there any new and improved technologies available to cooperative farmers in Imo State? Are these farmers aware of any improved technologies available in Imo State? And what are the bases for adopting these technologies if they are available? Unfortunately no single research on Imo State farmers and ADP technologies was identified to answer these questions. To fill this gap, the researcher decided to embark on this study in order to examine the adoption of root and tuber technologies among cooperative farmers participating in Imo state Agricultural Development Programme.

\section{Research Methods}

\subsection{Research Design}

This study was a descriptive survey which examined the adoption of root and tuber technologies among cooperative farmers in Imo State. Research survey according to Okeke, Olize and Eze (2008), consists of asking questions, collecting and analyzing data from a supposedly representative members of the population at a single point in time with a view to determining the current situation of that population and with respect to one or more variables under investigation. According to these authors, a descriptive survey is used to scan a wide field of issues, in order to measure or describe any generalize features, the dominant method of survey research are to administration of copies 
of questionnaire and interview.

\subsection{Area of the Study}

This study was conducted in Imo State, which is located in the South East Zone of Nigeria. The State is mainly Christians, with Igbo and English as their dialects. Imo State lies within latitudes $4^{\circ} 45^{\prime} \mathrm{N}$ and $7^{\circ} 15^{\prime} \mathrm{N}$, and longitude $6^{\circ} 50^{\prime} \mathrm{E}$ and $7^{\circ} 25^{\prime} \mathrm{E}$ with an area of around $5,100 \mathrm{sq} \mathrm{km}$. It is bordered by Abia State on the East, by the River Niger and Delta State on the West, by Anambra State to the North and Rivers State to the South with twenty seven (27) Local Government Areas and 558 autonomous communities which are grouped into three (3) senatorial zones namely Okigwe, Orlu and Owerri senatorial zones (Wikipedia, 2015).

The state is rich in natural resources including crude oil, natural gas, lead, zinc. Economically exploitable flora like the iroko, mahogany, obeche, bamboo, rubber tree, yam, cassava and oil palm predominate (Wikipedia, 2015).

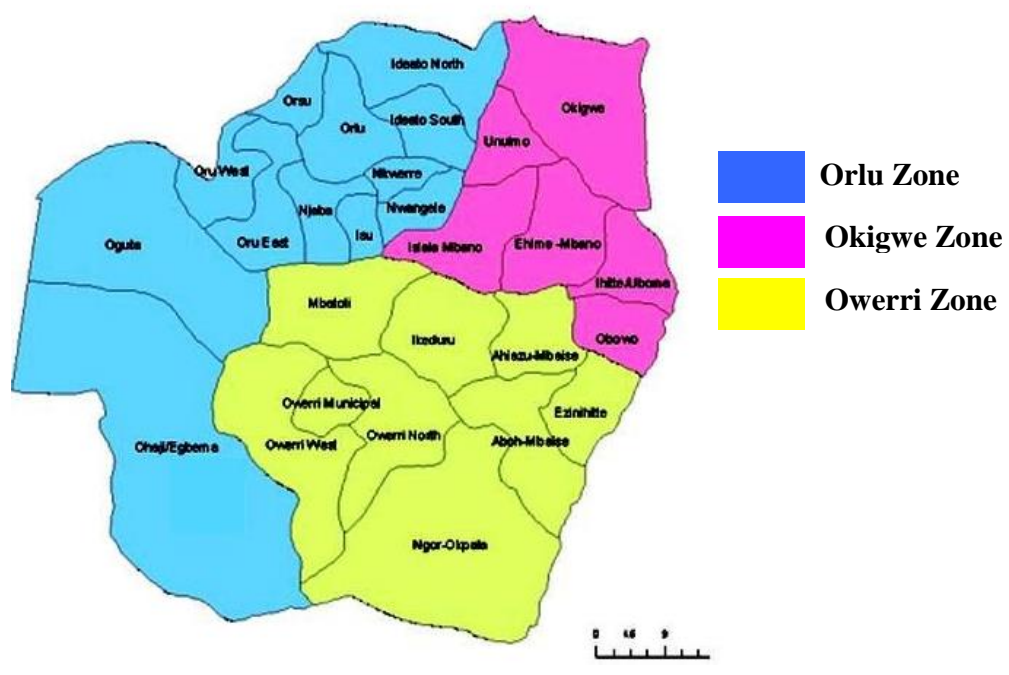

Figure 1. Map showing the three (3) senatorial zones of Imo State and their local government areas

\subsection{Sample Size and Sampling Techniques}

Taro Yamani formula was used to determine a sample of 113 from the population of 338 members of agricultural cooperatives participating in the ADP in Imo State. For the purpose of allocation of sample stratum, R. Kumaisons formula was adopted. Below is the R. Kumaisons formula for sample size distribution:

$\mathrm{Nh}=\mathrm{nNh}$

$\mathrm{N}$

Where $\mathrm{n}=$ Total sample size

$\mathrm{Nh}=$ The number of items in each stratum in the population

$\mathrm{N}=$ Population size

$\mathrm{nh}=$ The number of units allocated to each stratum

$\mathrm{n}=113$

$\mathrm{nh}=$ No of in each zone: Zone $\mathrm{A}=87$, Zone $\mathrm{B}=141$,

Zone $\mathrm{C}=110$

Substituting in the above formula:

Zone $\mathrm{A} ;=>\mathrm{nh}=\frac{113 \times 87}{338}=29$

Zone $\mathrm{B} ; \mathrm{nh}=\frac{113 \times 141}{338}=47$ 
Zone $\mathrm{C} ; \mathrm{nh}=\frac{113 \times 110}{338}=37$

\subsection{Validation and Reliability of Instrument}

The measuring instrument used in this study was carefully designed elicit opinionated, factual and interpretative information pertinent to the purpose and objective of the study and was given to lecturers/researchers in the Department of Cooperative Economics and Management for corrections. On the reliability of the instrument, it was subjected to test - retest pilot study in order to prove the level of reliability of the research instrument. A pilot study conducted in Orlu Senatorial Zone of Imo State using 10 respondents (members) of farmers' cooperative societies in the study area and the scores obtained at two intervals indicated correlation coefficient of 0.88 adoption level and 0.72 improved technology. This was an indication of reasonable stability.

\section{Method of Data Analysis}

Data collected during the field survey were descriptively analyzed using simple percentage and frequency distribution models, as well as mean model.

Socio - economic characteristics of the respondents and specific objective one were analyzed using simple percentage and frequency distribution models while specific objectives 2- 4 were analyzed using mean model. Hence, decision was based on mean less than 2.5 as low while mean greater than 3-0 as high. On the test of hypotheses, Ftest using the linear regression model of the ordinary least square (OLS) approach was used to test the hypothesis one so as to ascertain the effect of farmers' gender, age, educational level, farm size and income on the level of RTEP technologies being promoted in the study area.

The model is implicitly specifies as follows;

$$
\mathrm{Y}=\mathrm{f}\left(\mathrm{x}_{1}, \mathrm{x}_{2}, \mathrm{x}_{3} \ldots \ldots . \mathrm{Xn}+\mathrm{ei}\right)
$$

The model is implicitly specifies as follows;

$$
\mathrm{Y}=\alpha+\beta_{1} \mathrm{x}_{1},+\beta_{2} \mathrm{x}_{2},+\beta_{3} \mathrm{x}_{3},+\beta_{4} \mathrm{x}_{4}, \ldots \ldots \mathrm{B}_{\mathrm{K}} \mathrm{x}_{\mathrm{K}},+ \text { ei }
$$

The double log form of the model is specified thus:

$$
\begin{gathered}
\log \mathrm{Y}=\alpha+\beta_{1} \log \mathrm{x}_{1},+\beta_{2} \log \mathrm{x}_{2},+\beta_{3} \log \mathrm{x}_{3},+\beta_{4} \log \mathrm{x}_{4}, \ldots \ldots \mathrm{B}_{\mathrm{K}} \log _{\mathrm{K}},+ \text { ei } \\
\mathrm{Y}=\alpha+\beta_{1} \log \mathrm{x}_{1},+\beta_{2} \log \mathrm{x}_{2},+\beta_{3} \log \mathrm{x}_{3},+\beta_{4} \log \mathrm{x}_{4}, \ldots \ldots . \mathrm{B}_{\mathrm{K}} \log _{\mathrm{K}},+ \text { ei semi } \log
\end{gathered}
$$

Where;

$$
\begin{array}{ll}
\alpha & =\text { intercept } \\
\mathrm{Y} & =\text { Level of adoption (adopted }=1 \text {, otherwise }=0) \\
\beta_{1}- & \beta_{5}=\text { Regression co-efficient } \\
\text { ei } \quad=\text { Error term designed to capture the effects of unspecified variables in the model. } \\
\mathrm{X}_{1}=\text { Age of farmers (yrs) } \\
\mathrm{X}_{2}=\text { Gender }(0=\text { male, } 1=\text { female) } \\
\mathrm{X}_{3}=\text { Level of education }(\mathrm{yrs}) \\
\mathrm{X}_{4}=\text { Land size (ha) } \\
\mathrm{X}_{5} \quad=\text { Income }(\text { High }=1 \text {, otherwise }=0) \\
\alpha \quad=\text { constant term }
\end{array}
$$

The $\alpha$ and $\beta$ are the parameters for estimation. While ei is the error term. The regression analysis was run using SPSS computer package.

\subsection{Hypotheses II and III}

Pearson correlation model at $0.5 \%$ significant level was used to test hypotheses 2 and 3 as to ascertain the relationship between variables under test.

\subsection{Hypotheses IV}

F- Test using the linear regression model of the ordinary least square (OLS) approach was also used to test the hypothesis four so as to ascertain the effect of adopting improved process RTEP technologies on the income level of 
the cooperative farmers in the study area.

The model is implicitly specifies as follows;

$$
\mathrm{Y}=\mathrm{f}\left(\mathrm{x}_{1}, \mathrm{x}_{2}, \mathrm{x}_{3} \ldots \ldots \mathrm{Xn}+\mathrm{ei}\right)
$$

The model is implicitly specifies as follows;

$$
\mathrm{Y}=\alpha+\beta_{1} \mathrm{x}_{1},+\beta_{2} \mathrm{X}_{2},+\beta_{3} \mathrm{x}_{3},+\beta_{4} \mathrm{x}_{4}, \ldots \ldots . \mathrm{B}_{\mathrm{K}} \mathrm{x}_{\mathrm{K}},+\mathrm{ei}
$$

The double $\log$ form of the model is specified thus:

$$
\begin{gathered}
\log Y=\alpha+\beta_{1} \log x_{1},+\beta_{2} \log x_{2},+\beta_{3} \log x_{3},+\beta_{4} \log x_{4}, \ldots \ldots B_{K} \log _{K},+ \text { ei } \\
Y=\alpha+\beta_{1} \log x_{1},+\beta_{2} \log x_{2},+\beta_{3} \log x_{3},+\beta_{4} \log x_{4}, \ldots \ldots . B_{K} \log _{K},+ \text { ei semi } \log
\end{gathered}
$$

Where;

$$
\begin{aligned}
& \alpha \quad=\text { intercept } \\
& Y \quad=\text { Income Level }(\text { High }=1 \text {, otherwise }=0 \text { ) } \\
& \beta_{1}-\beta_{6}=\text { Regression co-efficient } \\
& \text { ei } \quad=\text { Error term designed to capture the effects of unspecified variables in the model. } \\
& X_{1}=\text { Grate made of stainless (adopted }=1 \text {, otherwise }=0 \text { ) } \\
& X_{2}=\text { Presser (adopted }=1 \text {, otherwise }=0 \text { ) } \\
& X_{3}=\text { Community fryer made of stainless steel (adopted = 1, otherwise =0) } \\
& \left.X_{4}=\text { Sifter (adopted }=1 \text {, otherwise }=0\right) \\
& \left.X_{5}=\text { Cooling table (adopted }=1 \text {, otherwise }=0\right) \\
& \left.X_{6}=\text { Cassava peeler (adopted }=1, \text { otherwise }=0\right) \\
& \alpha \quad=\text { constant term }
\end{aligned}
$$

The $\alpha$ and $\beta$ are the parameters for estimation. While ei is the error term. The regression analysis was run using SPSS computer package.

\section{Results and Discussion}

\subsection{Socio-Economic Characteristics of the Respondents (Cooperative Farmers)}

Table 1 above shows that 15(13.2\%) of the respondents are between the ages of $1-20$ years, while 32(28.3\%) of the respondents are between the ages of $21-40$ years. The Table also reveals that 48(42.6\%) of the respondents are between the ages of 41-60years and 18(15.9\%) of the respondents are between the ages of 61 years and above. This implies that the majority of the respondents are between the ages of $41-60$ years.

Table 2 reveals that $51(45.1 \%)$ of the respondents were male, while $62(54.9 \%)$ of the respondents were female. This implies that there were more female cooperative farmers in the study area than male.

Table 3 shows that $24(21.3 \%)$ of the respondents are single. $68(60.2 \%)$ of the respondents are married. The Table further reveals that $10(8.8 \%)$ of the respondents are divorced from their marriages and $11(9.7 \%)$ of the respondents are either widow or widower. This implies that the majority of the cooperative farmers in the study area are married men and women.

Table 4 shows the educational status of the respondents. 27(23.8\%) of the respondents had acquired first school leaving certificate (FSLC). 46 (40.7\%) of the respondents acquired Senior Secondary School Certificate (SSCE). The table further revealed that $17(15.1 \%)$ of the respondents acquired either a university or polytechnic certificate while $20(20.4 \%)$ of the respondents had no formal education at all. This implies that the majority of the respondents are senior secondary school certificate holders.

On the occupation of the respondents, Table 5 reveals that 76(67.3\%) of the respondents are into farming only. $24(21.2 \%)$ of the respondents are into farming and trading business. The Table above further shows that no single respondent is a civil servant but $13(11.5 \%)$ of the respondents are into farming and schooling. This implies that the majority of the respondents are into farming only.

Table 6 shows that $75(66.4 \%)$ of the respondents have between $1-5$ family size. $18(15.9 \%)$ of the respondents have between $6-10$ family size. $8(7.1 \%)$ of the respondents have between $11-15$ family size while $12(10.6 \%)$ of the respondents have no child. This implies that the family size of the majority of the respondents is between $1-5$. 
Table 7 shows that $30(26.5 \%)$ of the respondents owned pieces of land between $0-1.9$ ha. $31(27.4 \%)$ of the respondents owned farmland size between $2-3.9$ ha. 39(34.6\%) of the respondents owned farmland size between 4 5.9ha while $13(11.5 \%)$ of the respondents farmland size is above 6ha. This implies that the majority of the respondents owned farmland size between $4-5.9$ ha.

Table 8 shows that $19(16.8 \%)$ of the respondents have being members of their cooperative societies for $1-3$ years. $53(46.9 \%)$ of the respondents are between $4-6$ years. 28(24.8\%) of the respondents are between $7-9$ years. While $13(11.5 \%)$ of the respondents have being members of their cooperative societies for 10 years and above. This implies that the majority of the respondents have being members of their cooperative societies for a period of $4-6$ years.

Table 1. Socio-economic characteristics of Cooperative Farmers $(n=113)$

\begin{tabular}{|c|c|c|c|}
\hline Socio-economic Variables & Categories & Frequency & Percentage (\%) \\
\hline \multirow{2}{*}{ Sex } & Male & 51 & 45.1 \\
\hline & Female & 62 & 54.9 \\
\hline \multirow{4}{*}{ Age } & $18-20$ & 15 & 13.2 \\
\hline & $21-40$ & 32 & 28.3 \\
\hline & $41-60$ & 48 & 42.6 \\
\hline & $61 \&$ Above & 18 & 15.9 \\
\hline \multirow{4}{*}{ Marital Status } & Single & 24 & 21.3 \\
\hline & Married & 68 & 60.2 \\
\hline & Widowed & 10 & 8.8 \\
\hline & Divorced & 11 & 9.7 \\
\hline \multirow{4}{*}{ Educational level } & No formal Education & 27 & 23.8 \\
\hline & Primary & 46 & 40.7 \\
\hline & Secondary & 17 & 15.1 \\
\hline & Tertiary & 23 & 20.4 \\
\hline \multirow{4}{*}{ Occupation } & Farming only & 76 & 67.3 \\
\hline & Farming/trading & 24 & 21.2 \\
\hline & Farming/Civil service & 0 & 0 \\
\hline & Farming/Student & 13 & 11.5 \\
\hline \multirow{4}{*}{ Household size (No) } & $1-5$ & 75 & 66.4 \\
\hline & $6-10$ & 18 & 15.9 \\
\hline & $11-15$ & 8 & 7.1 \\
\hline & None & 12 & 10.6 \\
\hline \multirow{4}{*}{ Land area owned (ha) } & $0-1.9$ ha & 30 & 26.5 \\
\hline & $2-3.9 \mathrm{ha}$ & 31 & 27.4 \\
\hline & $4-5.9$ ha & 39 & 34.6 \\
\hline & $>6 h a$ & 13 & 11.5 \\
\hline \multirow{4}{*}{ Length of membership (yrs) } & $1-3$ years & 19 & 16.8 \\
\hline & $4-6$ years & 53 & 46.9 \\
\hline & $7-9$ years & 28 & 24.8 \\
\hline & 10years and above & 13 & 11.5 \\
\hline
\end{tabular}

Source: Field Data, 2019. 


\subsection{The RTEP Technologies Being Promoted By Imo State Agricultural Development Programme}

Table 2 shows various improved cassava varieties, 20(17.7\%) of the respondents indicated that ADP promotes cassava - TMS 305SS in the study area. 32(28.3\%) of the respondents indicated that ADP promotes Cassava - TMS 30 in the study area. The Table further reveals that 20(17.7\%) of the respondents also indicated that ADP promotes Cassava - TMS 30572 in the study area and 41(36.3\%) of the respondents indicated that ADP promotes all cassava improved varieties listed above. This implies that, the majority of the respondents strongly agreed and indicated that ADP in the study area promotes Cassava - TMS 305SS, Cassava - TMS 30 and Cassava -TMS (30572) in the study area.

Table 4.9 shows various improved yam varieties, 18(15.9\%) of the respondents indicated that ADP promotes Yam ABANA 85 in the study area. 27(23.9\%) of the respondents indicated that ADP promotes Yam - ADAKA 96 in the study area. The Table further reveals that $20(17.7 \%)$ of the respondents also indicated that ADP promotes Yam EKPE 88 in the study area and 48(42.5\%) of the respondents indicated that ADP promotes all yam improved varieties listed above. This implies that, the majority of the respondents strongly agreed and indicated that ADP in the study area promotes Yam - ABANA 85, Yam - ADAKA 96 and Yam - EKPE 88 among farmers in the study area.

On the improved processing technologies being promoted by ADP in the study area, Table 4.11 shows that $12(10.6 \%)$ of the respondents indicated grate made of stainless steel. $9(8 \%)$ of the respondents also indicated that presser community fryer made of stainless steel is promoted. 12(10.6\%) of the respondents indicated that sifter is promoted. Both $14(12.4 \%)$ and $18(15.9 \%)$ of the respondents indicated cooling table and cassava peeler respectively are being promoted in the study area by ADP. And 48(42.5\%) of the respondents indicated that all improved processing methods mentioned above are being promoted by the ADP in the study area. This implies that the majority of the respondents indicated all improved processing methods mentioned above are being promoted by the ADP in the study area.

Table 2. Distributions based on improved varieties promoted by the ADP

\begin{tabular}{llcc}
\hline Improved Varieties promoted & Variables & Frequency & Percentage \% \\
\hline \multirow{4}{*}{ Cassava } & Cassava - TMS 305SS & 20 & 17.7 \\
& Cassava - TMS 30 & 32 & 28.3 \\
& Cassava -TMS 30572 & 20 & 17.7 \\
& All of the above & 41 & 36.3 \\
\hline \multirow{3}{*}{ Yam } & Yam - ABANA 85 & 18 & 15.9 \\
& Yam - ADAKA 96 & 27 & 23.9 \\
& Yam - EKPE 88 & 20 & 17.7 \\
& All of the above & 48 & 42.5 \\
\hline
\end{tabular}

Source: Field Data, 2019. 
Table 3. Distributions based on improved processing technologies/ agronomic practices promoted by the ADP

\begin{tabular}{llll}
\hline Improved processing technologies promoted & Variables & Frequency & Percentage \% \\
\hline & Grate made of stainless steel & 12 & 10.6 \\
& Presser & & \\
& Community fryer made of & \\
& stainless steel & 9 & 8 \\
& Sifter & 12 & 10.6 \\
& Cooling table & 14 & 12.4 \\
& Cassava peeler & 18 & 15.9 \\
& All of the above & 48 & 42.5 \\
& & & \\
Improved agronomic practices promoted & Recommended spacing & 14 & 12.4 \\
& Sole cropping & 28 & 24.8 \\
& Use of fertilizer & 8 & 7.1 \\
& Use of herbicides & 4 & 3.5 \\
& Use of pesticides & 4 & 3.5 \\
& All of the above & 55 & 48.7 \\
\hline
\end{tabular}

Source: Field Data, 2019.

ADP promotes some improved agronomic practices in the study area. Table 3 shows that $14(12.4 \%)$ of the respondents indicated that 'recommended spacing method' is promoted. $28(24.8 \%)$ of the respondents indicated that ADP promotes 'sole cropping' methods in the study area. 'Use of fertilizer, herbicides and pesticides' methods are also promoted in the study area by ADP as indicated by $8(7.1 \%), 4(3.5 \%)$ and $4(3.5 \%)$ of the respondents respectively while $55(48.7 \%)$ of the respondents indicated that ADP in the study area promotes all the above mentioned agronomic practices among farmers. This implies that the majority of the respondents indicated that ADP in the study area promotes all the above mentioned agronomic practices among farmers.

4.3 The Farmers' Level of Awareness of Various Varieties of Root and Tuber Technologies and Agronomic Practices

Table 4. Mean calculation of the respondents based on the level of awareness of various varieties of root and tuber technologies and agronomic practices in the study area

\begin{tabular}{llllllllllll}
\hline S/N & Item & SA & A & I & D & SD & FX & N & X & Remark \\
\cline { 2 - 5 } 1 & 5 & 4 & 3 & 2 & 1 & & & & \\
\hline & $\begin{array}{l}\text { You are fully aware of the various improved } \\
\text { varieties of root and tuber technologies and other }\end{array}$ & 46 & 34 & 16 & 12 & 5 & 443 & 113 & 3.92 & High \\
$\begin{array}{l}\text { agronomic practices promoted by ADP. } \\
\text { You always access these technologies/practices } \\
\text { whenever you need them. }\end{array}$ & 24 & 22 & 14 & 39 & 14 & 342 & 113 & 3.03 & High \\
\hline
\end{tabular}

Table 4 sought to analysis the farmers' level of awareness of various varieties of root and tuber technologies and agronomic practices being promoted by ADP in the study area. Table 4 shows that most of the respondents are fully aware of various improved varieties of root and tuber technologies and other agronomic practices promoted by ADP in the study area as indicated with a mean score of ' 3.92 ' High.

On the farmers' access to these technologies/practices whenever they need them, the Table above indicated a 'high' access rate with a mean score of ' 3.03 '. 
4.4 The Farmers'Level of Adoption Of RTEP Technologies Among Cooperative Farmers In The Study Area

Table 5. Mean calculation of the respondents based on the level of adoption of RTEP technologies in the study area

\begin{tabular}{|c|c|c|c|c|c|c|c|c|c|c|}
\hline \multirow{2}{*}{$\mathbf{S} / \mathbf{N}$} & \multirow{2}{*}{ Item } & SA & $\mathbf{A}$ & I & D & SD & \multirow{2}{*}{ FX } & \multirow{2}{*}{$\mathbf{N}$} & \multirow{2}{*}{$\mathbf{X}$} & \multirow{2}{*}{ Remark } \\
\hline & & 5 & 4 & 3 & 2 & 1 & & & & \\
\hline 1 & $\begin{array}{l}\text { You often accessed } \\
\text { these technologies } \\
\text { promoted by RTEP. }\end{array}$ & 27 & 39 & 21 & 12 & 14 & 392 & 113 & 3.46 & High \\
\hline 2 & $\begin{array}{l}\text { You are satisfied with } \\
\text { the level of access to } \\
\text { RTEP technologies. }\end{array}$ & 17 & 24 & 12 & 34 & 26 & 311 & 113 & 2.75 & Moderate \\
\hline
\end{tabular}

Source: Field Data, 2019.

Table 5 also sought to analysis the farmers' level of adoption of RTEP Technologies among cooperative farmers in the study area. On the farmers' accessed to these technologies often promoted by RTEP, the table indicated a mean score of ' 3.46 ' High. While ascertaining the satisfaction of the farmers on their level of access to RTEP Technologies, thetable above indicated a mean score of ' 2.75 ' low.

\subsection{The Effect of RTEP Technologies on Farmers Income in the Study Area}

Table 6. Mean calculation of the respondents based on the effect of RTEP technologies on farmers' income in the study area

\begin{tabular}{|c|c|c|c|c|c|c|c|c|c|c|}
\hline \multirow{2}{*}{$\mathbf{S} / \mathbf{N}$} & \multirow{2}{*}{ Item } & $\mathbf{S A}$ & $\mathbf{A}$ & I & D & SD & \multirow{2}{*}{ FX } & \multirow{2}{*}{$\mathbf{N}$} & \multirow{2}{*}{$\mathbf{X}$} & \multirow{2}{*}{ Remark } \\
\hline & & 5 & 4 & 3 & 2 & 1 & & & & \\
\hline 1 & $\begin{array}{l}\text { What was your income } \\
\text { level before you } \\
\text { adopted } \\
\text { technologies? }\end{array}$ & 12 & 14 & 11 & 43 & 33 & 268 & 113 & 2.37 & Low \\
\hline 2 & $\begin{array}{l}\text { You consider the } \\
\text { performance(s) of these } \\
\text { technologies to be } \\
\text { satisfactory. }\end{array}$ & 26 & 34 & 20 & 21 & 12 & 380 & 113 & 3.36 & High \\
\hline 3 & $\begin{array}{l}\text { What is your income } \\
\text { level after you adopted } \\
\text { RTEP technologies? }\end{array}$ & 36 & 42 & 9 & 17 & 9 & 418 & 113 & 3.69 & High \\
\hline
\end{tabular}

Source: Field Data, 2019.

On ascertaining the effect of RTEP technologies on farmers income in the study area, Table 6 indicated that income level of farmers before adoption of RTEP Technologies was low with a mean score of '2.37'. On their satisfaction for the performance of these technologies adopted, the Table indicated a high level of satisfaction with a mean score of '3.36'.

The Table above further reveals that income level of farmers remarkably improved after the adoption of RTEP Technologies of ADP in the study area with a mean score of ' 3.69 ', high.

\subsection{Test of Hypotheses}

\section{Hypothesis I:}

$\mathrm{Ho}_{1}$ - The RTEP technologies being promoted are not significantly influenced by farmers' gender, age, educational level, farm size and income. 
Table 7. Regression Result for the RTEP technologies being promoted as influenced by farmers' gender, age, educational level, farm size and income

\begin{tabular}{llll}
\hline Item & Coefficient & Standard Error & t.Statistics \\
\hline (Constant) & -.100 & .104 & -.965 \\
Age & .366 & .085 & $4.318^{*}$ \\
Educational Status & .900 & .061 & $14.757^{*}$ \\
Farm Size & .515 & .076 & $6.797^{*}$ \\
Gender & -.423 & .113 & $-3.738^{*}$ \\
Income & -.261 & .050 & $-5.191^{*}$ \\
\hline
\end{tabular}

Dependent Variable: Tech. promoted/adoption (SPSS computer based-software);

$\mathrm{R}^{2}=0.960$;

Adj $R^{2}=0.957$

$\mathrm{F}=400.892(\mathrm{p}=0.000)$.

The analysis of data on Table 7 revealed that the multiple co-efficient $\mathrm{R}^{2}=0.960$ shows a relatively high degree of relationship between the dependent variable and the independent variables; age, educational level, gender, farm size and income. In other words, there is a high degree of association in between the dependent variable and the independent variables taken together. The Adjusted $R^{2}=\left(\right.$ denoted by $A d j . R^{2}$ ) was found out to be 0.957 . This implies that $96 \%$ of the variation in the level of RTEP technologies promoted and adopted is explained by the changes in variables in the model. The F-test is significant showing that the joint effect of variables in the model on the level of adoption of RTEP - ADP is significant.

With regards to the influence of individual variables, it was found out that age, educational level, gender, farm size and income by cooperative farmers are significant determinants on the level of adoption of RTEP - ADP among cooperative farmers in the study area. This however, appears to suggest that a change in these variables will lead to the cooperative farmers either increasing or decreasing their level of adoption of RTEP - ADP in the study area.

In view of the significant relationship at $0.5 \%$ of regression estimate of age, educational level, gender, farm size and income by cooperative farmers are significant determinants on the level of adoption of RTEP - ADP among cooperative farmers in the study area; we are inclined to reject the null hypothesis.

This result however, reconfirms the earlier study by Ezeh, Anyiro, Ogbonnaya and Obioma (2013) on the impact of agricultural development programmes (ADP) on rural women contact farmers' poverty levels in Aguata, agricultural zone of Abia State which concluded that critical determinants of gross expenditure of the rural women contact farmers and its effect to adoption of ADP improved technologies include household size, farm size, labour use levels and farm incomes at given levels of significance.

\section{Hypothesis II:}

$\mathrm{Ho}_{2}$ : There is no significant relationship between the adoption of various varieties of root and tuber technology and the level of awareness by the farmers in the study area. 
Table 8. Correlation Result for the adoption of various varieties of root and tuber technology and the level of awareness by the farmers

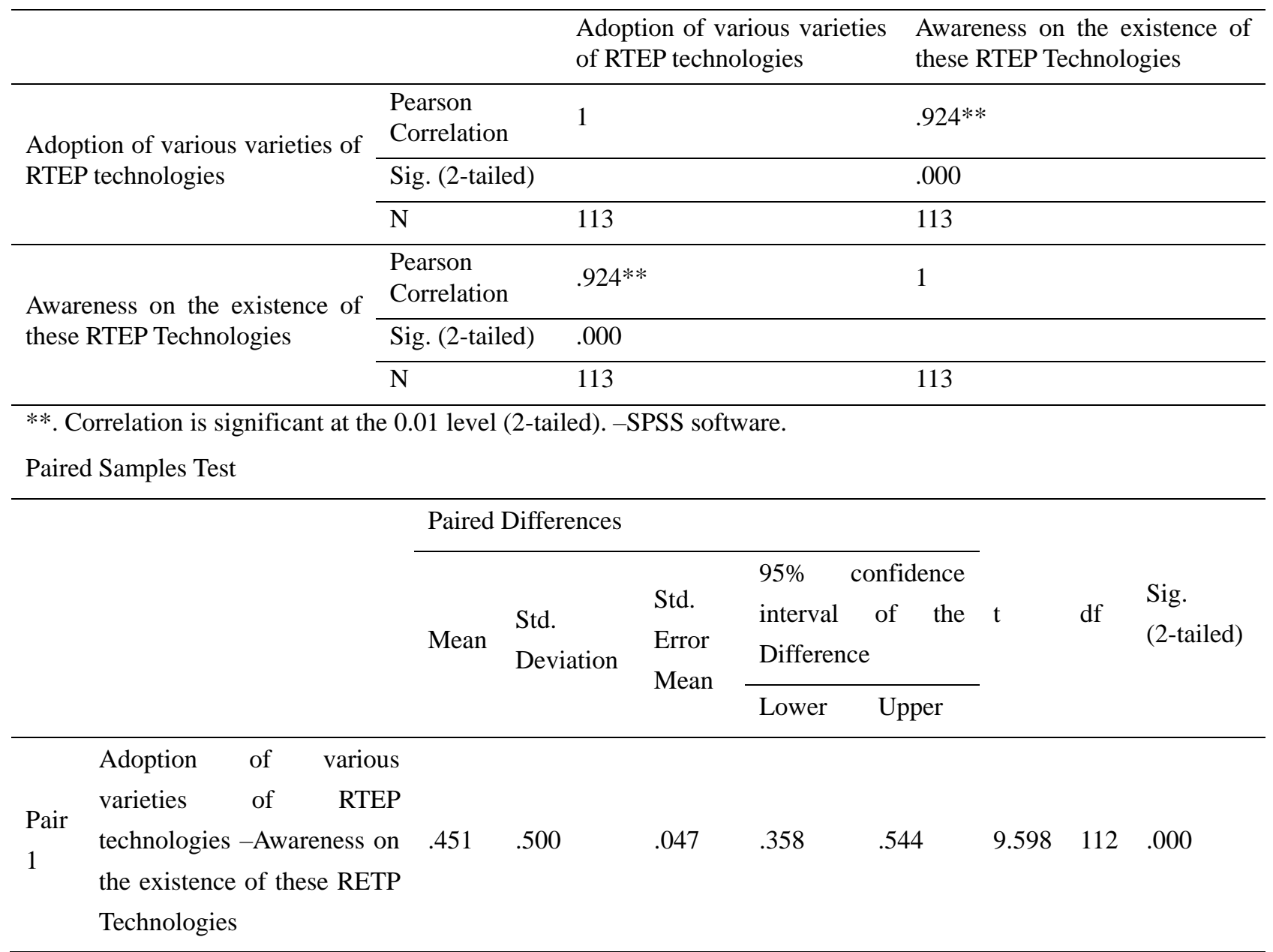

On the table above it is clearly shown that there is a high positive relationship between the adoption of various varieties of root and tuber technology and the level of awareness by the farmers in the study area put together. Thus $r$ $=0.924, \mathrm{n}=113, \mathrm{p}=0.000$.

$\mathrm{Z}$ - test was also conducted using the difference between the sample means in order to accept or reject the null hypothesis. It is shown that t- ratio value of 9.598 was significant at the conventional $5 \%$ level. As a result of this, the null hypothesis as stated above is rejected and we therefore conclude that there is significant relationship between the adoption of various varieties of root and tuber technology and the level of awareness by the farmers in the study area.

The implication of this is that low level of farmers' awareness of ADP Improved varieties technologies can adversely affect its level of adoption. This finding justifies the mean values obtained in Table 8 which revealed that farmers' fully accessed these technologies often promoted by RTEP in the study area as indicated with a mean score of ' 3.46 ' High. This result also reconfirmed the earlier study of Ekwere, Edem and Agbasi, (2014) on adoption of root and tuber technologies among farmers which concluded that there is a relationship between the farmers' level of adoption of ADP Technologies and farmers' level of awareness.

\section{Hypothesis III:}

$\mathrm{Ho}_{3}$ - There is no significant relationship between cooperative farmers' level of adoption and accessibility of RTEPADP technologies. 
Table 9. Correlation Result for cooperative farmers' level of adoption and accessibility of RTEP- ADP technologies

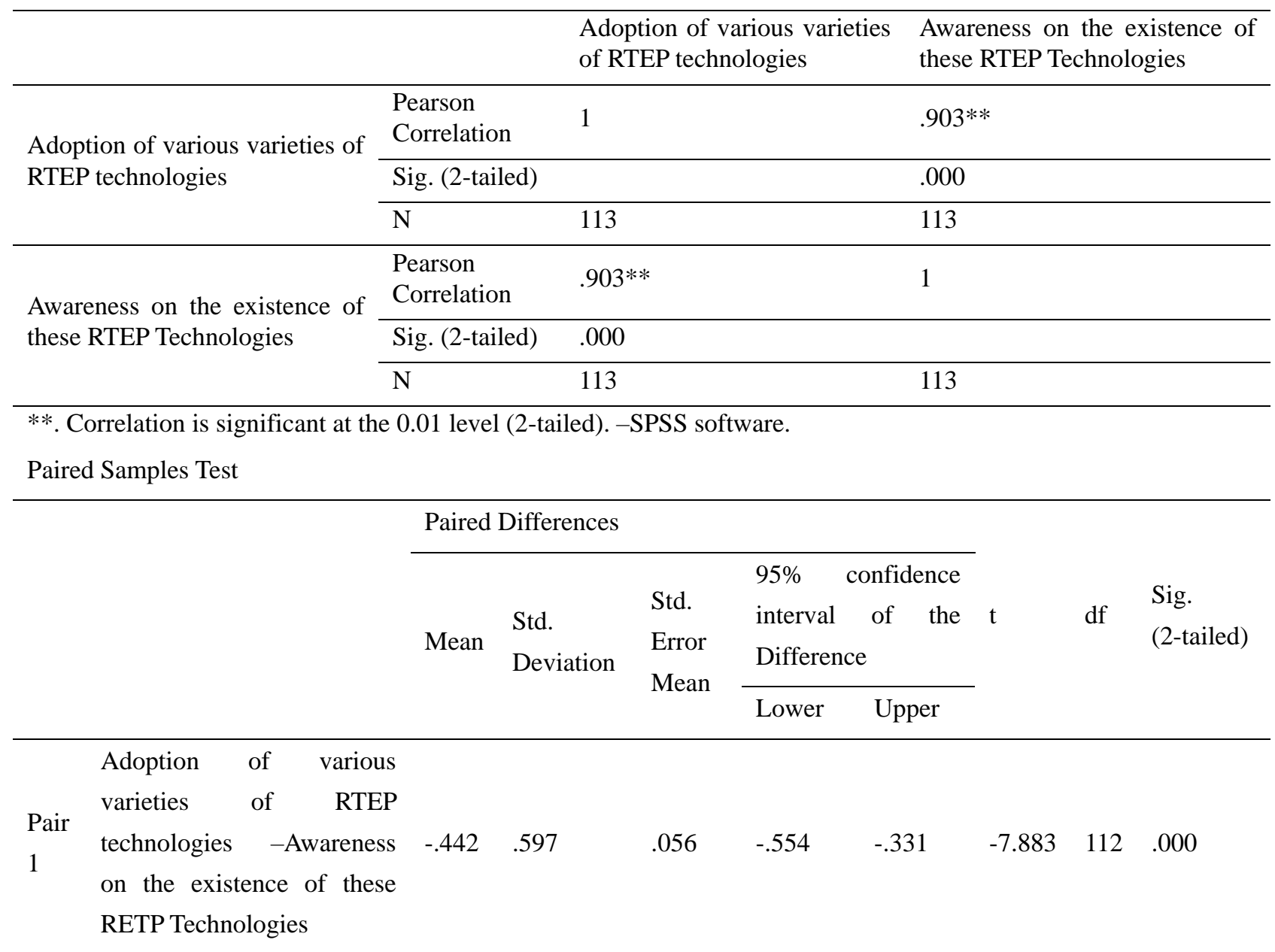

Table 9 clearly shows that there is a high positive relationship between cooperative farmers' level of adoption and accessibility of RTEP- ADP technologies in the study area put together. Thus $r=0.903, n=113, p=0.000$.

$\mathrm{Z}$ - Test was also conducted using the difference between the sample means in order to accept or reject the null hypothesis. It is shown that t- ratio value of - 7. 883 was significant at the conventional 5\% level. As a result of this, the null hypothesis as stated above is rejected and we therefore conclude that there is a significant relationship between cooperative farmers' level of adoption and accessibility of RTEP- ADP technologies in the study area.

The implication of this is that none or low farmers' access to ADP improved technologies can adversely affects farmers their level of adoption. This finding justifies the mean values obtained in Table 9 which revealed high level of accessibility of RTEP Technologies and its adoption in the study area with a mean score of ' 3.46 ', high. This result further reconfirmed the earlier studies of Ekwere et al (2014) and Ezeh et al (2013) which these authors in their various findings concluded that regular access to improved farming technologies by rural farmers certainly enhances their level of adoption which tends to improve their economic activities and brings about an improved income level among farmers.

\section{Hypothesis IV:}

$\mathrm{Ho}_{4}$ - The income level of the farmers is significantly influenced by the adoption of RTEP processing technologies in the study area. 
Table 10. Regression Result for income level of the farmers as influenced by the adoption of RTEP processing technologies in the study area

\begin{tabular}{llll}
\hline Item & Coefficient & Standard Error & t.Statistics \\
\hline (Constant) & -.110 & .153 & .756 \\
Grater made of stainless & .783 & .119 & $6.587^{*}$ \\
Presser & .231 & .089 & $2.592^{*}$ \\
Community fryer made of stainless steel & & & \\
Sifter & .215 & .143 & -1.507 \\
Cooling table & -.017 & .128 & -.137 \\
Cassava peeler & -.196 & .159 & -1.236 \\
& .286 & .139 & $2.062^{*}$ \\
\hline
\end{tabular}

Dependent Variable: Income level after adoption (SPSS software).

$\mathrm{R}^{2}=0.879$.

Adj $R^{2}=0.872$.

$\mathrm{F}=128.593(\mathrm{p}=0.000)$.

Table 10 revealed that the multiple co-efficient $\mathrm{R}^{2}=0.879$ shows a relatively high degree of relationship between the dependent variable and the independent variables; Grater made of stainless steel, Presser, Community fryer made of stainless steel, Sifter, Cooling table and cassava peeler. In other words, there is a high degree of association in between the dependent variable and the independent variables taken together. The Adjusted $R^{2}=\left(\right.$ denoted by Adj. $\left.R^{2}\right)$ was found out to be 0.872 . This implies that $87 \%$ of the variation in the level of farmers' income and its influence by the adoption of RTEP processing Technologies is explained by the changes in variables in the model. The F-test is significant showing that the joint effect of variables in the model on the income level of the farmers after adoption of RTEP technologies is significant.

With regards to the influence of individual variables, it was found that Grater made of stainless steel, Presser and Cooling table by cooperative farmers are significant determinants that influence their income level after adoption in the study area. This however, appears to suggest that a change in these variables will lead to the cooperative farmers either increasing or decreasing their level of income in the study area.

In view of the significant relationship at $0.5 \%$ of regression estimate of Grater made of stainless steel, Presser and Cooling table by cooperative farmers are significant determinants that influence their income level among cooperative farmers in the study area; we are inclined to reject the null hypothesis. The implication of this is that without income, farmers certainly will not have access to RTEP - ADP Technologies and their economic activities will not have a significant different. This result also reconfirms the earlier study by Madu and Wakili (2012) that conducted a study to assess the effect of the ADP activities on the wellbeing of the rural farmers in Adamawa State. The results indicated that Adamawa ADP had positive and significant impact on rural farmers' productivity, income, access to credit, standard of living as measured by assets ownership. However, the project did not have significant impact on the rural infrastructure, adoption of improved technologies and farm sizes, even though the change before and after ADP activities was positive.

\subsection{Summary of Findings}

This study examines the adoption of root and tuber technologies among cooperative farmers in Imo State Agricultural Development Programme, using a sample of all registered farmer-based groups (cooperatives) participating in ADP and all the staff of RTEP-ADP Imo state. The study employed descriptive survey design, correlation and OLS regression analysis. Based on the tests conducted on the data collected and the analyses of the results, this study found that the majority of the respondents indicated that ADP in the study area promotes improved crop varieties which include; Cassava - TMS 305SS, Cassava - TMS 30 and Cassava -TMS (30572) and Yam ABANA 85, Yam - ADAKA 96 and Yam - EKPE 88 in the study area.

It was also found that improved processing technologies such as grater made of stainless steel, presser, community fryer made of stainless steel, sifter, cooling table and cassava peeler were also promoted by the ADP in the study area. 
Apart from these improved processing technologies promoted, improved agronomic practices are also promoted by ADP in the study area, of which Sole Cropping Method and others are highly promoted. The study found that cooperative farmers in the study area are fully aware of various improved varieties of root and tuber technologies and other agronomic practices promoted by ADP. And they have a fair access to these technologies/practices whenever they need them. Ascertaining the influence of RTEP technologies on farmers' income, the study found that income level of farmers before adoption of RTEP Technologies was low. However, farmers after adoption of these technologies experienced a remarkably improvement on their income.

It was also found that age, educational level, gender, farm size and income by cooperative farmers were significant determinants that influence the promotion and adoption of RTEP - ADP among cooperative farmers in the study area; the null hypothesis one was rejected. Findings from this study showed a high positive relationship between the adoption of various varieties of root and tuber technology and the level of awareness by the farmers in the study area put together. Thus $\mathrm{r}=0.924, \mathrm{n}=113, \mathrm{p}=0.000$. And the $\mathrm{Z}-$ test conducted to ascertain the difference between the sample means in order to accept or reject the null hypothesis showed t- ratio value of 9.598 was significant at the conventional 5\% level. As a result of this, the null hypothesis II was rejected. Findings from this study further showed a high positive relationship between cooperative farmers' level of adoption and accessibility of RTEP- ADP technologies in the study area put together. Thus $\mathrm{r}=0.903, \mathrm{n}=113, \mathrm{p}=0.000$. And $\mathrm{Z}$ - Test conducted $\mathrm{t}-$ ratio value of - 7. 883 was significant at the conventional 5\% level. As a result of this, the null hypothesis III was rejected and we therefore concluded that there is a significant relationship between cooperative farmers' level of adoption and accessibility of RTEP- ADP technologies in the study area.

Finally, the study revealed the multiple co-efficient $R^{2}=0.879$ which shows a relatively high degree of relationship between the dependent variable and the independent variables; And the Adjusted $\mathrm{R}^{2}=\left(\right.$ denoted by Adj. $\mathrm{R}^{2}$ ) was found out to be 0.872 . This implies that $87 \%$ of the variation in the level of farmers' income and its influence on the adoption of RTEP processing Technologies is explained by the changes in variables in the model. The F-test was significant showing that the joint effect of variables in the model on the income level of the farmers after adoption of RTEP technologies is significant. In view of the significant relationship at $0.5 \%$ of regression estimate of Grater made of stainless steel, Presser and Cooling table by cooperative farmers were significant determinants that influence income level among cooperative farmers in the study area; we rejected the null hypothesis IV and accepted the alternate.

\section{Conclusion}

Based on the findings, it would be instructive to conclude that age, educational level, gender, farm size and income by cooperative farmers were significant determinants that influence the promotion and adoption of RTEP - ADP among cooperative farmers and a significant relationship exists between the level of adoption and the level of awareness of RTEP - ADP Technologies by cooperative farmers in the study area. The study also concludes that a high positive relationship between cooperative farmers' level of adoption and accessibility of RTEP- ADP technologies in the study area put together.

It was further noted that the ADP system has made quite some noticeable impacts on the rural dwellers. It is hoped that the strategy will continue to enjoy all necessary support to be able to register greater impact and continually contributes to rural livelihood and food security in Nigeria, what is required is to build on the gains and ensure sustainability of the system. This can be achieved through, among others: increased political support by the governments, increased community/beneficiary participation especially in infrastructure development and maintenance; commercialization of more ADP activities and transfer of some to the private sector and finally, intensification of extension research linkage especially via the opportunity offered by the National Agricultural Research Project (NARP) which will ensure that only appropriate technologies are generated and transferred by the system. It was however, recommended that improved farming technologies by ADP should always be made available to the farmers at a far reduced or subsidized costs to encourage more farmers to access it since It was very clear in the finding that cooperative farmers in the study area were aware of various improved varieties of root and tuber technologies and other agronomic practices promoted by ADP in the study area, but had very little access to these technologies among others.

\section{References}

Adewumi, B. A.,Okunola, A. A. \& Faseyi, O. W. (2005). Large scale grain structures and their management in the humid part of Nigeria. In E. Y. H. Bobobee and A. Bart- Plange (Eds.), Hunger Without Frontiers (pp. 126-131). WASAE, Kumasi Ghana. 
Deji, O. (2005). Membership of Co-operative Societies and Adoption Behaviour of Women Farmers: Implication for Rural Development. Journal of Social Science, 10(2). https://doi.org/10.1080/09718923.2005.11892472

Ekwere, G., Edem, I. \& Agbasi, O. (2014). Adoption of Root And Tuber Technologies Among Farmers (Agricultural Development Programme-ADP). International Journal of Environment, 3(4). https://doi.org/10.3126/ije.v3i4.11741

FAO. (2013). Nigeria-land Use \& Crop Production Data. Rome: United Nations Food and Agricultural Organisation. IFAD. 2009. Agriculture in the Federal Republic of Nigeria. Rome: International Fund for Agricultural Development.

Idachaba, F. S. (1980). Agricultural Research Policy in Nigeria. Technology and Engineering (P. 70).

Igbeka, J. C. (1996). Agro-processing Machinery and Equipment Manufacturing in Nigeria. Paper presented at the National Workshop on Appropriate Mechanization FGN/NIR.AI Agricultural and Rural Development Programme, Mechanization Sub-programme NCAM, Ilorin, 10-15 November, 1996.

Nsoanya, L. N., \& Nenna, M. G. (2011). Adoption of Improved Cassava Production Technologies In Anambra-East Local Government Area of Anambra State Nigeria. JORIND, 9(2). Retrieved from www.transcampus.org., www.ajol.info/journals/jorind

Nwakwo, U. M., Peters, K. J., \& Bolkemann, W. (2009). Can Cooperative Membership and Participation Affect Adoption Decisions? Issues for Sustainable Biotechnology Dissemination. AgroBio Forum, 12(3\&4), 437-451.

Nweke, F. (2004). Challenges in cassava transformation in Nigeria and Ghana (pp. 1-118). Environment and production. Technology divisions 1FPRI, 2033K street NW Washington DC 20006 USA.

Network for Agricultural Mechanization in Africa - NAMA. (1992). Report of an Expert Consultation on the Establishment of a Network for Agricultural Mechanization in Africa. Food and Agricultural Division. The Commonwealth Secretariat, Nairobi and Kenya.

Okoedo-Okojie, D. U. \& Onemolease, E.A. (2009). Factors Affecting the Adoption of Yam Storage Technologies in the Northern Ecological Zone of Edo State, Nigeria. Journal of Human Ecology, 27(2), 155-160. https://doi.org/10.1080/09709274.2009.11906205

Oni, K. C. (2003). Mechanization as a Vehicle for Rapid Agricultural Development. Invited Lecture to Participants of Senior Executive Course No. 25, National Institute for Policy and Strategic Studies Kuru - Nigeria. 30th June.

Sandra, R., Breemer, Fox, J., Poars, S., \& Graig, J. (2004) Gender Variable in Agricultural Research. A Report prepared for the Women in Development officer US (pp. 3-4).

Ugwu, B. O., Felix, I., \& Dixion, A. G. O. (1996). Spread and performance of improved Cassava varieties in Nigeria. Collaborative study of Cassava in Africa, IITA, P.M.B. 532 Ibadan, Nigeria Paper No. 15, 20-26. 